\title{
Potret Pembelajaran Daring LATSAR CPNS Angkatan 19 pada Masa Pandemi Covid 19 di Lingkungan PPSDMA KESDM
}

\author{
${ }^{1 \text { st }}$ Ahmad Helmi; ${ }^{2 n d}$ Irfan Choiruddin; \\ 12 Pusat Pengembangan Sumber Daya Manusia Aparatur
}

\begin{abstract}
This study aims to analyze Whole of Government learning subject through online classes at Latsar CPNS, a cooperation program of the Ministry of Education and Culture's Employees Education and Training Center with Ministry of Energy and Mineral Resources PPSDM Aparatur during the COVID-19 pandemic at PPSDM Aparatur. Qualitative research methods were selected with a quasi-experimental analysis approach. The results of the study were as follow: the result of the class average post test score was 95.6 or very satisfying, the highest score per participant was 100 or very satisfying and the lowest was 81 or satisfactory. The advantage of online learning is the increase in participants' understanding of WOG learning materials and classes that are not boring. The drawbacks are the lack of understanding of the participants, time management and non-multiple choice tests. Suggestions for improvement are to increase the discussion of learning material, replace essays questions with with multiple choice questions, and increase the number and variety of questions. In general, online learning was considered positive and effective by participants so that it could be continued both during the pandemic and after the pandemic period ended normally.
\end{abstract}

\section{ABSTRAK}

Penelitian ini bertujuan menganalisis pembelajaran Whole of Government melalui kelas daring pada Latsar CPNS Kerjasama Pusdiklat Pegawai Kemendikbud dengan PPSDM Aparatur, Kementerian ESDM dalam masa pandemi COVID-19 di PPSDM Aparatur. Metode penelitian kualitatif dipilih dengan pendekatan analisa kuasi ekperimen. Hasil penelitian adalah sebagai berikut: hasil nilai post-test rata-rata kelas adalah 95.6 atau sangat memuaskan, nilai per peserta tertinggi dengan nilai 100 atau sangat memuaskan dan terendah 81 atau memuaskan. Kelebihan dari pembelajaran daring adalah meningkatnya pemahaman peserta terhadap materi pembelajaran WOG dan kelas yang tidak membosankan. Kekurangannya adalah pemahaman peserta yang kurang, manajemen waktu dan tes non pilihan ganda. Saran perbaikan adalah menambah pembahasan materi pembelajaran, bentuk soal dengan esai diganti dengan soal pilihan ganda, dan menambah jumlah dan variasi soal. Secara umum pembelajaran daring dinilai positif dan efektif oleh peserta sehingga dapat dilanjutkan baik pada masa pandemi maupun setelah masa pandemi ini berakhir normal.

\section{ARTICLE HISTORY}

Submited: $22 / 02 / 2021$

Accepted: 03/03/2021

Published: 30/04/202

\section{KEYWORDS}

Latsar CPNS, Pelatihan,

Daring, Pandemic

CPNS latsar, Training, Online,

Pandemic. 


\section{Pendahuluan}

Pemerintah resmi menetapkan wabah virus corona (Covid-19) sebagai bencana nasional. Penetapan status bencana nasional itu tercantum dalam Keputusan Presiden Nomor 12 Tahun 2020 tanggal 13 April 2020 tentang Penetapan Bencana Non alam Penyebaran Covid19 Sebagai Bencana Nasional Pandemi COVID-19 telah merubah tatanan kehidupan"1). Kita menghadapi tantangan-tantangan baru termasuk bagaimana menjalankan kehidupan sehari-hari. Kita masuk dalam era bernama Adaptasi Kebiasaan Baru. Jumlah pasien positif corona di Indonesia hingga 20 November 2020 mencapai 488.310 orang. Dari jumlah tersebut, 15.678 orang meninggal dunia, dan 410.552 pasien dinyatakan sembuh ${ }^{22}$.

Hal tersebut menyebabkan terjadinya perubahan kebijakan dalam banyak hal, termasuk dalam penyelenggaraan pelatihan. Sesuai Peraturan Kepala Lembaga Administrasi Negara (LAN) RI Nomor 12 Tahun 20183) tentang Pedoman Penyelenggaraan Pelatihan Dasar Calon Pegawai Negeri Sipil Golongan III, maka Penyelenggaraan Pendidikan dan Pelatihan (DIKLAT) Prajabatan dilaksanakan dengan nomenklatur baru ialah Pelatihan Dasar Kader PNS, sebagai salah satu jenis pelatihan yang strategis pasca UU ASN dalam rangka pembentukan kemampuan bersikap dan bertindak professional. Namun, sehubungan masa pandemi COVID-19 yang terjadi saat ini maka proses pembelajaran latsar dilaksanakan dengan pola pembelajaran jarak jauh (distance learning) sesuai Surat Edaran Kepala LAN No.10/ K.1/HKM.02.3/2020, sebagai upaya kewaspadaan dan pencegahan penularan infeksi virus corona $^{4}$. Di lingkungan Kementerian Energi dan Sumber Daya Mineral (ESDM), pelatihan tatap muka (luring) dihentikan dan digantikan dengan pelatihan secara daring. Tujuan penelitian ini adalah untuk menganalisis pembelajaran Whole of Government (WOG) melalui Pembelajaran Latsar CPNS Golongan III Kerjasama Pusdiklat Pegawai Kemendikbud dengan PPSDM Aparatur Angkatan 19 TA 2020.

Dalam UU. No.5 Tahun 2014 tentang Aparatur Sipil Negara di pasal 70 ditegaskan : (1) setiap pegawai ASN memiliki hak dan kesempatan untuk pengembangan kompetensi, antara lain melalui pendidikan dan pelatihan (diklat), kursus, seminar, dan penataran ${ }^{5}$.

Pelaksanaan pengembangan kompetensi bagi PNS secara offline bisa dilakukan melalui elearning atau sering disebut sebagai pelatihan dalam jaringan (daring). Dalam pelatihan elearning, ada beberapa hal yang perlu menjadi perhatian bagi pengajar, diantaranya adalah kemampuan membahasakan materi ajar menjadi digital dan interaktif dimana dalam pelaksanaan pembelajarannya menggunakan media Learning Management System (LMS). LMS adalah aplikasi perangkat lunak untuk kegiatan dalam jaringan, program pembelajaran elektronik (e-learning program), dan isi pelatihan. Dan hal ini menjadi keharusan bagi pengajar untuk terus mengembangkan materi ajar digital dan interaktif tersebut.

Pada beberapa penelitian sebelumnya, pembelajaran secara e-learning bagi Aparatur Sipil Negara (ASN) menunjukkan hasil positif dan efektif, meskipun ada beberapa perbaikan yang perlu dilakukan.

\section{Tinjauan Pustaka}

Pembelajaran pada hakikatnya adalah suatu proses mengatur, mengorganisasi lingkungan yang ada disekitar peserta didik, sehingga dapat menumbuhkan dan mendorong peserta didik untuk melakukan proses belajar. Pembelajaran juga dikatakan sebagai proses memberikan bimbingan atau bantuan kepada peserta didik dalam melakukan proses belajar. 
Trianto dalam Pane \& Dasopang (2017, hlm. 338 $)^{6}$ ) menjelaskan tentang pembelajaran adalah sebagai berikut: Pembelajaran adalah aspek kegiatan yang kompleks dan tidak dapat dijelaskan sepenuhnya. Secara sederhana, pembelajaran dapat diartikan sebagai produk interaksi berkelanjutan antara pengembangan dan pengalaman hidup. Pada hakikatnya, pembelajaran dalam makna kompleks adalah usaha sadar dari seorang pendidik untuk membelajarkan peserta didiknya (mengarahkan interaksi peserta didik dengan sumber belajar lain) dengan maksud agar tujuannya dapat tercapai. Menurut Undang-undang Republik Indonesia Nomor 20 tahun 20037) tentang Sistem Pendidikan Nasional, bahwa pembelajaran adalah proses interaksi pendidik dengan peserta didik dan sumber belajar yang berlangsung dalam suatu lingkungan belajar. Sedangkan Hamalik dalam Fakhrurrazi $\left(2018\right.$, hlm. 86) ${ }^{8)}$ menyatakan bahwa pembelajaran adalah suatu kombinasi yang tersusun meliputi unsur-unsur manusiawi (peserta didik dan pendidik), material (buku, papan tulis, kapur dan alat belajar), fasilitas (ruang kelas, audio visual), dan proses yang saling mempengaruhi mencapai tujuan pembelajaran. Pembelajaran juga dapat dikatakan sebagai suatu sistem, karena pembelajaran merupakan suatu kegiatan yang memiliki tujuan yaitu untuk memberikan pengetahuan kepada peserta didik. Pembelajaran merupakan suatu proses penyampaian informasi pengetahuan melalui interaksi dari pendidik kepada peserta didik, juga merupakan suatu proses memberikan bimbingan yang terencana serta mengkondisikan atau merangsang peserta didik agar dapat belajar dengan baik, dan kegiatan pembelajaran dapat ditandai dengan adanya interaksi edukatif yang terjadi, yaitu pendidik kepada peserta didik atau peserta didik kepada pendidik secara andragogi. Selain itu pendidik juga harus menyiapkan pembelajaran secara inovatif yang mampu merangsang peserta didik untuk semangat dalam melaksanakan kegiatan pembelajaran. Dapat disimpulkan bahwa pembelajaran adalah suatu kegiatan interaksi yang dilakukan oleh pendidik kepada peserta didik dengan tujuan agar peserta didik mempunyai pengetahuan. Pembelajaran juga merupakan suatu proses kegiatan belajar mengajar yang di dalamnya berisi pemberian materi pembelajaran, informasi pengetahuan, kegiatan membimbing peserta, serta pemberian rangsangan agar peserta dapat termotivasi sampai akhirnya mampu mencapai tujuan yang telah ditetapkan.

\section{Pembelajaran Daring}

Istilah daring merupakan akronim dari "dalam jaringan", yaitu suatu kegiatan yang dilaksanakan dengan sistem daring yang memanfaatkan internet. Menurut Bilfaqih \& Qomarudin (2015, hlm. 1) $)^{9)}$ "pembelajaran daring merupakan program penyelenggaraan kelas pembelajaran dalam jaringan untuk menjangkau kelompok target yang masif dan luas". Thorme dalam Kuntarto (2017, hlm. 102) ${ }^{10)}$ "pembelajaran daring adalah pembelajaran yang menggunakan teknologi multimedia, kelas virtual, CD ROM, streaming video, pesan suara, email dan telepon konferensi, teks online animasi, dan video streaming online". Sementara itu Rosenberg dalam Alimuddin, Tawany \& Nadjib $(2015, \mathrm{hlm} .338)^{11)}$ menekankan bahwa e-learning merujuk pada penggunaan teknologi internet untuk mengirimkan serangkaian solusi yang dapat meningkatkan pengetahuan dan keterampilan. Menurut Ghirardini dalam Kartika (2018, hlm. 27) ${ }^{12)}$ "daring memberikan metode pembelajaran yang efektif, seperti berlatih dengan adanya umpan balik terkait, menggabungkan kolaborasi kegiatan dengan belajar mandiri, personalisasi pembelajaran berdasarkan kebutuhan 
mahapeserta didik dan menggunakan simulasi dan permainan". Sementara itu menurut Menurut Peraturan Menteri Pendidikan dan Kebudayaan (PERMENDIKBUD) No. 109 Tahun $2013^{13)}$ pendidikan jarak jauh adalah proses belajar mengajar yang dilakukan secara jarak jauh melalui penggunaan berbagai media komunikasi. Dengan adanya kemajuan teknologi informasi dan komunikasi membawa perubahan dan kemajuan diberbagai sektor terutama pada bidang pendidikan. Peranan dari teknologi informasi dan komunikasi pada bidang pendidikan sangat penting dan mampu memberikan kemudahan kepada pendidik dan peserta didik dalam proses pembelajaran. Pembelajaran daring ini dapat diselenggarakan dengan cara masif dan dengan peserta didik yang tidak terbatas. Selain itu penggunaan pembelajaran daring dapat diakses kapanpun dan dimana pun sehingga tidak adanya batasan waktu dalam penggunaan materi pembelajaran. Dari pengertian di atas, dapat disimpulkan bahwa pembelajaran daring atau e-learning merupakan suatu pembelajaran yang memanfaatkan teknologi dengan menggunakan internet dimana dalam proses pembelajarannya tidak dilakukan dengan face to face tetapi menggunakan media elektronik yang mampu memudahkan peserta didik untuk belajar kapanpun dan dimanapun.

Tung dalam Mustofa, Chodzirin, \& Sayekti (2019, hlm. 154) ${ }^{14}$ menyebutkan karakteristik dalam pembelajaran daring antara lain: 1) Materi ajar disajikan dalam bentuk teks, grafik dan berbagai elemen multimedia, 2) Komunikasi dilakukan secara serentak dan tak serentak seperti video conferencing, chats rooms, atau discussion forums, 3) Digunakan untuk belajar pada waktu dan tempat maya, 4) Dapat digunakan berbagai elemen belajar berbasis CDROM untuk meningkatkan komunikasi belajar, 5) Materi ajar relatif mudah diperbaharui, 6) Meningkatkan interaksi antara peserta didik dan fasilitator, 7) Memungkinkan bentuk komunikasi belajar formal dan informal, 8) Dapat menggunakan ragam sumber belajar yang luas di internet Selain itu Rusma dalam Herayanti, Fuadunnazmi, \& Habibi (2017, hlm. 211) ${ }^{[15]}$ mengatakan bahwa karaktersitik dalam pembelajaran elearning antara lain: 1) Interactivity (interaktivitas), 2) Independency (kemandirian), 3) Accessibility (aksesibilitas), 4) Enrichment (pengayaan). Pembelajaran daring harus dilakukan sesuai dengan tata cara pembelajaran jarak jauh. Menurut PERMENDIKBUD Nomor 109 tahun 2013 ciri-ciri dari pembelajaran daring adalah: 1) Pendidikan jarak jauh adalah proses belajar mengajar yang dilakukan secara jarak jauh melalui penggunaan berbagai mendia komunikasi. 2) Proses pembelajaran dilakukan secara elektronik (e-learning), dimana memanfaatkan paket informasi berbasis teknologi informasi dan komunikasi untuk kepentingan pembelajaran yang dapat diakses oleh peserta didik kapan saja dan dimana saja. 3) Sumber belajar adalah bahan ajar dan berbagai informasi dikembangkan dan dikemas dalam bentuk yang berbasis teknologi informasi dan komunikasi serta digunakan dalam proses pembelajaran. 4) Pendidikan jarak jauh memiliki karakteristik bersifat terbuka, belajar, mandiri, belajar tuntas, menggunakan teknlogi informasi dan komunikasi, menggunakan teknologi pendidikan lainnya, dan berbentuk pembelajaran terpadu perpendidikan tinggi. 5) Pendidikan jarak jauh bersifat terbuka yang artinya, pembelajaran yang diselenggarakan secara fleksibel dalam hal penyampaian, pemilihan dan program studi dan waktu penyelesaian program, jalur dan jenis pendidikan tanpa batas usia, tahun ijazah, latar belakang bidang studi, masa registrasi, tempat dan cara belajar, serta masa evaluasi hasil belajar. Dari penejelasan tentang karakteristik/ciri dari pembelajaran daring maka dapat disimpulkan bahwa karakteristik/ciri pembelajaran daring yaitu dengan menggunakan media elektronik, pembelajaran yang dilaksanakan menggunakan internet, pembelajaran dapat dilaksanakan kapanpun dan dimanapun serta pembelajaran daring bersifat terbuka. 
Bilfaqih dan Qomarudin $(2105, \mathrm{hlm} .4)^{16)}$ menjelaskan beberapa manfaat dari pembelajaran daring sebagai berikut: 1) Meningkatkan mutu pendidikan dan pelatihan dengan memanfaatkan multimedia secara efektif dalam pembelajaran. 2) Meningkatkan keterjangkauan pendidikan dan pelatihan yang bermutu melalui penyelenggaraan pembelajaran dalam jaringan. 3) Menekan biaya penyelenggaraan pendidikan dan pelatihan yang bermutu melalui pemanfaatan sumber daya bersama. Selain itu Manfaat pembelajaran daring menurut Bates dan Wulf dalam Mustofa, Chodzirin, \& Sayekti (2019, hlm. 154) terdiri atas 4 hal, yaitu: 1) Meningkatkan kadar interaksi pembelajaran antara peserta didik dengan pendidik atau instruktur (enhance interactivity), 2) Memungkinkan terjadinya interaksi pembelajaran dari mana dan kapan saja (time and place flexibility), 3) Menjangkau peserta didik dalam cakupan yang luas (potential to reach a global audience), 4) Mempermudah penyempurnaan dan penyimpanan materi pembelajaran (easy updating of content as well as archivable capabilities) Adapun manfaat e-learning menurut Hadisi dan Muna (2015, hlm. 127) ${ }^{17)}$ adalah: 1) Adanya fleksibilitas belajar yang tinggi. Artinya, peserta didik dapat mengakses bahan-bahan belajar setiap saat dan berulang-ulang. 2) Peserta didik dapat berkomunikasi dengan pendidik setiap saat. Artinya, peserta didik dapat lebih memantapkan penguasaannya terhadap materi pembelajaran.

Kelebihan pembelajaran daring/e-learning menurut Hadisi dan Muna (2015, hlm. 130) ${ }^{18)}$ adalah: a) Biaya, e-learning mampu mengurangi biaya pelatihan. Pendidikan dapat menghemat biaya karena tidak perlu mengeluarkan dana untuk peralatan kelas seperti penyediaan papan tulis, proyektor dan alat tulis. b) Fleksibilitas waktu e-learning membuat pelajar dapat menyesuaikan waktu belajar, karena dapat mengakses pelajaran kapanpun sesuai dengan waktu yang diinginkan. c) Fleksibilitas tempat e-learning membuat pelajar dapat mengakses materi pelajaran dimana saja, selama komputer terhubung dengan jaringan Internet. d) Fleksibilitas kecepatan pembelajaran e-learning dapat disesuaikan dengan kecepatan belajar masing-masing peserta didik. e) Efektivitas pengajaran e-learning merupakan teknologi baru, oleh karena itu pelajar dapat tertarik untuk mencobanya juga didesain dengan instructional design mutakhir membuat pelajar lebih mengerti isi pelajaran. f) Ketersediaan On-demand E-learning dapat sewaktu-waktu diakses dari berbagai tempat yang terjangkau internet, maka dapat dianggap sebagai "buku saku" yang membantu menyelesaikan tugas atau pekerjaan setiap saat. Adapun kelebihan pembelajaran daring/elearning menurut Seno \& Zainal (2019, hlm. 183) ${ }^{19)}$ adalah: a) Proses log-in yang sederhana memudahkan peserta didik dalam memulai pembelajaran berbasis e-learning. b) Materi yang ada di e-learning telah disediakan sehingga mudah diakses oleh pengguna. c) Proses pengumpulan tugas dan pengerjaan tugas dilakukan secara online melalui google docs ataupun form sehingga efektif untuk dilakukan dan dapat menghemat biaya. d) Pembelajaran dilakukan dimana saja dan kapan saja. Sedangkan kelebihan pembelajaran daring menurut Hendri (2014, hlm. 24) ${ }^{20)}$ diantaranya adalah: a) Menghemat waktu proses belajar mengajar b) Mengurangi biaya perjalanan c) Menghemat biaya pendidikan secara keseluruhan (infrastruktur, peralatan, buku-buku) d) Menjangkau wilayah geografis yang lebih luas e) Melatih pembelajar lebih mandiri dalam mendapatkan ilmu pengetahuan.

Kekurangan pembelajaran daring/e-learning menurut Hadisi dan Muna (2015, hlm. 131) ${ }^{21)}$ antara lain: a) Kurangnya interaksi antara pendidik dan peserta didik bahkan antar-peserta didik itu sendiri yang mengakibatkan keterlambatan terbentuknya values dalam proses belajar-mengajar. b) Kecenderungan mengabaikan aspek akademik atau aspek sosial dan sebaliknya mendorong tumbuhnya aspek bisnis. c) Proses belajar dan mengajarnya 
cenderung ke arah pelatihan dari pada pendidikan. d) Peserta didik yang tidak mempunyai motivasi belajar yang tinggi cenderung gagal. e) Tidak semua tempat tersedia fasilitas internet (mungkin hal ini berkaitan dengan masalah tersedianya listrik, telepon, ataupun komputer). Adapun kekurangan pembelajaran daring/e-learning menurut Seno \& Zainal (2019, hlm. 183) antara lain: a) Tampilan halaman login yang masih membutuhkan petunjuk lebih dalam. b) Materi yang diberikan kurang luas dan disajikan dalam bentuk Bahasa inggris sehinggga merepotkan dalam mempelajarinya. c) Adanya pengumpulan tugas yang tidak terjadwal serta tidak adanya pengawasan secara langsung atau face to face dalam pengerjaan tugas yang membuat pengumpulan tugas menjadi molor. d) Materi pembelajaran menjadi kurang dimengerti saat pembelajaran tidak ditunjang dengan penjelasan dari pendidik secara langsung. Sedangkan kekurangan pembelajaran daring/elearning menurut Munir dalam Sari (2015, hlm. 28) ${ }^{22)}$ adalah: a) Penggunaan e-learning sebagai pembelajaran jarak jauh, membuat peserta didik dan pendidik terpisah secara fisik, demikian juga antara peserta didik satu dengan lainnya, yang mengakibatkan tidak adanya interaksi secara langsung antara pengajar dan peserta didik. Kurangnya interaksi ini dikhawatirkan bisa menghambat pembentukan sikap, nilai (value), moral, atau sosial dalam proses pembelajaran sehingga tidak dapat diaplikasikan dalam kehidupan sehari-hari. b) Teknologi merupakan bagian penting dari pendidikan, namun jika lebih terfokus pada aspek teknologinya dan bukan pada aspek pendidikannya maka ada kecenderungan lebih memperhatikan aspek teknis atau aspek bisnis/komersial dan mengabaikan aspek pendidikan untuk mengubah kemampuan akademik, perilaku, sikap, sosial atau keterampilan peserta didik. c) Proses pembelajaran cenderung ke arah pelatihan dan pendidikan yang lebih menekankan aspek pengetahuan atau psikomotor dan kurang memperhatikan aspek afektif. d) Pengajar dituntut mengetahui dan menguasai strategi, metode atau teknik pembelajaran berbasis Teknologi Ilmu Komputer (TIK). Jika tidak mampu menguasai, maka proses transfer ilmu pengetahuan atau informasi jadi terhambat dan bahkan bisa menggagalkan proses pembelajaran. e) Proses pembelajaran melalui e-learning menggunakan layanan internet yang menuntut peserta didik untuk belajar mandiri tanpa menggantungkan diri pada pengajar. Jika peserta didik tidak mampu belajar mandiri dan motivasi belajarnya rendah, maka ia akan sulit mencapai tujuan pembelajaran. $f$ ) Kelemahan secara teknis yaitu tidak semua peserta didik dapat memanfaatkan fasilitas internet karena tidak tersedia atau kurangnya komputer yang terhubung dengan internet. g) Jika tidak menggunakan perangkat lunak sumber terbuka, bisa mendapatkan masalah keterbatasan ketersediaan perangkat lunak yang biayanya relatif mahal. h) Kurangnya keterampilan mengoperasikan komputer dan internet secara lebih optimal Dari penjelasan di atas maka kelebihan dan kekurangan dari pembelajaran daring atau e-learning yaitu mempermudah proses pembelajaran, pembelajaran dapat dilakukan dimana saja, mudahnya mengakses materi, melatih pembelajar lebih mandiri, serta pengumpulan tugas secara online. Tetapi ada juga kekurangan dari pembelajaran daring/e-learning yaitu tidak adanya pengawasan karena pembelajaran dilaksanakan secara face to face, jika peserta didik tidak mampu belajar mandiri dan motivasi belajarnya rendah, maka ia akan sulit mencapai tujuan pembelajaran serta kurangnya pemahaman terhadap materi, serta pengumpulan tugas yang tidak terjadwalkan. 


\section{Kuasi Eksperimen}

Metode penelitian merupakan cara pemecahan penelitian yang dilaksanakan secara terencana dan cermat dengan maksud mendapatkan fakta dan simpulan agar dapat memahami, menjelaskan, meramalkan, dan mengendalikan keadaan. Terdapat berbagai jenis-jenis metode penelitian diantaranya penelitian kualitatif dan penelitian kuantitatif. Menurut McCusker, K., \& Gunaydin, S. (2015) ${ }^{233}$, pemilihan penggunaan metode kualitatif dalam hal tujuan penelitiannya adalah untuk memahami bagaimana suatu komunitas atau individu-individu dalam menerima isu tertentu. Dalam hal ini, sangat penting bagi peneliti yang menggunakan metode kualitatif untuk memastikan kualitas dari proses penelitian, sebab peneliti akan menginterpretasi data yang telah dikumpulkannya. Pada penelitian ini, peneliti menggunakan jenis penelitian kualitatif dengan menggunakan metode eksperimen semu (Quasi experiment). Metode kuasi eksperimen atau eksperimen semu yang penulis gunakan diartikan sebagai penelitian yang mendekati penelitian eksperimen. Jenis penelitian eksperimen semu banyak digunakan dalam bidang pendidikan atau bidang lain yang subyek penelitiannya adalah manusia yang tidak dapat dimanipulasi dan dikontrol secara intensif. Sugiyono $(2013, \mathrm{hlm} .107)^{24)}$ mengemukakan pendapatnya sebagai berikut: "Dalam penelitian eksperimen ada perlakuan (treatment), dengan demikian metode penelitian yang digunakan untuk mencari pengaruh perlakuan tertentu terhadap yang lain dalam kondisi yang terkendalikan". Subana (2011, hlm 103) ${ }^{25)}$ menyatakan bahwa tujuan penelitian semu ialah "Untuk memperkirakan kondisi-kondisi eksperimen sungguhan dalam keadaan dimana tidak memungkinkan untuk mengontrol dan atau memanipulasi semua variabel yang relevan".

\section{Metode Penelitian}

Penelitian ini merupakan kuasi eksperimen dengan rancangan eksperimen pre dan post test ${ }^{26)}$. Bersifat kualitatif dengan sumber data utama adalah kata-kata, tindakan, dan dokumen ${ }^{27}$. Penelitian ini dilakukan pada Pembelajaran Latsar CPNS Golongan III Kerjasama Pusdiklat Pegawai Kemendikbud dengan PPSDM Aparatur Angkatan 19 TA 2020 dalam pembelajaran Whole of Government pada masa pandemi COVID-19 di PPSDM Aparatur pada hari Rabu, tanggal 7 September 2020 dengan peserta sebanyak 44 orang. Data capaian peserta dilakukan dengan evaluasi formatif secara online menggunakan Microsoft form (pre test dan post test), sedangkan pendapat peserta tentang kekurangan, kelebihan dan saran perbaikan kelas daring dikumpulkan menggunakan google form setelah pembelajaran daring selesai dilaksanakan. Data yang terkumpul melalui google form sejumlah 42, ada 2 data peserta yang tidak masuk. Data dianalisis secara logika-induktif yaitu proses berpikir yang menggunakan logika untuk memahami pola dan kecenderungan dalam data melalui tiga tahap yaitu pengkodean, mendeskripsikan karakteristik utama, dan menginterpretasikan data ${ }^{28}$. Hasil penelitian disajikan secara deskriptif.

\section{Hasil dan Pembahasan}

Sebaran lokasi peserta dari Pulau Sulawesi tersebar di 3 provinsi sebagai berikut: 1) Provinsi Gorontalo di kota Kendari dan kabupaten Kolaka; 2) Provinsi Maluku di kota Ambon; dan 3) Provinsi Papua Barat di kota Manokwari. PPSDM Aparatur bekerjasama dengan BLU Kementerian ESDM (PPSDM KEBTKE) sebagai pelaksana Latsar CPNS Kerjasama. Pengajar 
melakukan pembelajaran Work From Home yang juga berlokasi di Bandung masuk dalam Wilayah Indonesia Barat (WIB). Lokasi pembelajar masuk dalam Wilayah Indonesia Tengah (WITA) dan Wilayah Indonesia Timur (WIT) yang terdapat perbedaan waktu satu jam dan dua jam dari WIB. Pembelajaran kelas daring sangat bergantung dengan kelancaran sinyal internet, kondisi sinyal internet menurut peserta adalah sebagai berikut:

Tabel 1. Kondisi Sinyal Internet Menurut Peserta

\begin{tabular}{|c|c|}
\hline Sinyal Internet & Jumlah Peserta \\
\hline Sangat Lancar & $1(2,4 \%)$ \\
\hline Lancar & $32(76,2 \%)$ \\
\hline Kurang Lancar & $9(21,4 \%)$ \\
\hline
\end{tabular}

Source: jawaban post test peserta pelatihan

Tidak ada peserta yang jaringan internetnya tidak lancar, sehingga mengganggu proses pembelajaran. Sebelum dilakukan pembelajaran kelas daring, peserta sudah belajar mandiri menggunakan modul yang sudah disiapkan di LMS SMILE, sehingga saat pembelajaran daring dapat dilakukan pendalaman materi melalui diskusi dengan berpedoman pada modul sebagai tindakan kuasi eksperimen. Untuk mengukur capaian tujuan pembelajaran dilakukan post test dengan soal yang dibuat berdasarkan modul dengan nilai rata-rata 95,6 atau sangat memuaskan. Adapun hasil post test seluruh peserta pembelajaran daring mata pelatihan Whole of Government adalah sebagai berikut:

Tabel 2. Kualifikasi Hasil Post Test Peserta

\begin{tabular}{|c|c|}
\hline Kualifikasi Nilai & Jumlah Peserta \\
\hline Sangat memuaskan & $36(82 \%)$ \\
\hline Memuaskan & $8(18 \%)$ \\
\hline
\end{tabular}

Source: jawaban post test peserta pelatihan

Tabel 3. Hasil Nilai Post Test Peserta

\begin{tabular}{|c|c|}
\hline Kualifikasi Nilai & Jumlah Peserta \\
\hline 100 & 5 \\
\hline 99 & 4 \\
\hline 98 & 7 \\
\hline 93 & 22 \\
\hline 83 & 2 \\
\hline 82 & 2 \\
\hline 81 & 2 \\
\hline
\end{tabular}


Tabel 4. Pendapat Peserta Tentang Ketercapaian Pembelajaran Whole Of Government Sesuai Modul

\begin{tabular}{|c|c|}
\hline Ketercapaian Materi & Jumlah Peserta \\
\hline $60-69 \%$ & $1(2,4 \%)$ \\
\hline $70-79 \%$ & $8(19 \%)$ \\
\hline $80-89 \%$ & $23(54,8 \%)$ \\
\hline $90-100 \%$ & $10(23,8 \%)$ \\
\hline
\end{tabular}

Source: jawaban post test peserta pelatihan

Tabel 5. Pendapat Peserta Kekurangan Dalam Pembelajaran Mata Pelatihan Whole Of Government

\begin{tabular}{|c|c|c|}
\hline $\begin{array}{l}\text { Jumlah } \\
\text { Peserta }\end{array}$ & $\begin{array}{c}\text { Pernyataan } \\
\text { Peserta }\end{array}$ & Solusi \\
\hline $\begin{array}{c}14 \\
(33,3 \%)\end{array}$ & $\begin{array}{l}\text { Kurangnya } \\
\text { pemahaman } \\
\text { materi }\end{array}$ & $\begin{array}{l}\text { Sebelum tatap muka secara daring peserta sudah ditugaskan } \\
\text { melakukan pembelajaran secara mandiri, data ini dapat } \\
\text { dijadikan bahan masukan agar dalam melakukan } \\
\text { pembelajaran secara mandiri peserta dilakukan pre test dan } \\
\text { post test sehingga sudah diketahui capaian hasil belajar } \\
\text { mandiri dan materi pembelajaran apa yang paling banyak } \\
\text { dijawab benar maupun paling banyak dijawab salah. } \\
\text { Sehingga ketika tatap muka daring dapat efektif membahas } \\
\text { materi-materi yang paling banyak dijawab salah oleh peserta } \\
\text { saat belajar mandiri. }\end{array}$ \\
\hline $3(7,1 \%)$ & $\begin{array}{l}\text { Terkendala } \\
\text { jaringan } \\
\text { internet }\end{array}$ & $\begin{array}{l}\text { Secara umum bahwa kelancaran jaringan internet peserta } \\
76,2 \% \text { menyatakan lancar, jika ada kendala internet yang } \\
\text { sedikit tidak stabil sangat tergantung pada provider yang } \\
\text { digunakan di lokasi peserta mengikuti pembelajaran,. Soal } \\
\text { post test dibuat sesuai dengan isi modul yang sudah } \\
\text { disiapkan dan dibuat secara berurutan berdasarkan bab-bab } \\
\text { dalam modul pada mata pelatihan Whole Of Government, } \\
\text { sehingga dimungkinkan saat mengerjakan post test peserta } \\
\text { menjawab sambil melihat modul. Hal ini masih } \\
\text { dimungkinkan karena post test merupakan tes formatif } \\
\text { bukan tes evaluasi kelulusan. }\end{array}$ \\
\hline $3(7,1 \%)$ & $\begin{array}{l}\text { Soal yang } \\
\text { diberikan } \\
\text { berupa } \\
\text { essay }\end{array}$ & $\begin{array}{l}\text { Bisa jadi hal ini karena peserta belum menguasai materi } \\
\text { pembelajaran dengan baik. Solusinya, soal bisa dirubah } \\
\text { menjadi pilihan ganda. }\end{array}$ \\
\hline 11 & $\begin{array}{c}\text { Tidak ada } \\
\text { kekurangan }\end{array}$ & - \\
\hline
\end{tabular}




\begin{tabular}{|c|c|c|}
\hline$(26,2 \%)$ & $\begin{array}{c}\text { dari } \\
\text { pelaksanaan } \\
\text { pre dan post } \\
\text { test }\end{array}$ & \\
\hline & $\begin{array}{c}\text { Waktu yang } \\
\text { kurang } \\
\text { dalam } \\
\text { pengerjaan }\end{array}$ & $\begin{array}{l}\text { Jika melihat dari hasil post test dengan nilai paling kecil } 81 \\
\text { (memuaskan) dan batas nilai terendah untuk lulus adalah } \leq \\
60 \text { (kualifikasi tidak memuaskan) maka dari sisi waktu } \\
\text { pelaksanaan post test dianggap sudah mencukupi. }\end{array}$ \\
\hline \multicolumn{2}{|c|}{ soal } & $23,8 \%)$ \\
\hline
\end{tabular}

Tabel 6. Pendapat Peserta Kelebihan Dalam Pembelajaran Mata Pelatihan Whole Of Government

\begin{tabular}{|c|c|}
\hline $\begin{array}{c}\text { Jumlah } \\
\text { Peserta }\end{array}$ & $\begin{array}{c}\text { Pernyataan Peserta } \\
\text { Metode pembelajaran tersebut mampu mempercepat pemahaman } \\
\text { terhadap materi yang diberikan. Pembelajaran ini tidak } \\
\text { membosankan dan lebih mudah untuk mengingat materi. Selain itu } \\
\text { juga dapat meningkatkan kecekatan peserta dalam mencari dan } \\
\text { menemukan jawaban, memudahkan peserta juga dalam memahami } \\
\text { materi seperti tentang pemahaman WOG, prinsip WOG, Isue dan } \\
\text { komitmen penerapan WOG, contoh contoh WOG dan jenis serta } \\
\text { bentuk egovernment, lebih menantang dan seru karena bisa } \\
\text { melatih untuk membaca dan berfikir cepat }\end{array}$ \\
\hline $5(11,9 \%)$ & Berpendapat efektif dan efisien dikarenakan pembelajaran lebih \\
praktis dan fleksibel.
\end{tabular}

Source: jawaban post test peserta pelatihan

Tabel 7. Saran Perbaikan Dari Peserta Terhadap Pembelajaran WoG

\begin{tabular}{|c|l|l|}
\hline $\begin{array}{c}\text { Jumlah } \\
\text { Peserta }\end{array}$ & \multicolumn{1}{|c|}{ Pernyataan peserta } & \multicolumn{1}{c|}{ Solusi } \\
\hline $\begin{array}{c}12 \\
(28,6 \%)\end{array}$ & $\begin{array}{l}\text { Menambah waktu pengerjaan } \\
\text { post test }\end{array}$ & $\begin{array}{l}\text { Dari hasil post test yang sudah di dapatkan } \\
\text { memiliki nilai paling kecil 81, sehingga } \\
\text { waktu yang ada dianggap sudah } \\
\text { mencukupi dan saran ini dapat diabaikan. }\end{array}$ \\
\hline 17 & $\begin{array}{l}\text { Menyatakan sudah baik dan } \\
\text { tidak ada perbaikan dari } \\
\text { pelaksanaan metode } \\
\text { pembelajaran ini. }\end{array}$ & - \\
\hline 9 & Menyatakan bahwa soal & Soal yang digunakan dalam pre test dan \\
\hline
\end{tabular}




\begin{tabular}{|l|l|l|}
\hline$(21,4 \%)$ & $\begin{array}{l}\text { kurang banyak dan kurang } \\
\text { variative. }\end{array}$ & $\begin{array}{l}\text { post test ini diambil dari modul mata } \\
\text { pelatihan dan disesuaikan dengan urutan } \\
\text { bab dalam pembelajaran, dan untuk } \\
\text { mengukur pemahaman peserta terhadap } \\
\text { materi pembelajaran ini maka soal pre test } \\
\text { dan post test dibuat sama. }\end{array}$ \\
\hline & $\begin{array}{l}\text { Menyatakan bahwa } \\
\text { pemahaman peserta } \\
\text { terhadap kuis dan } \\
\text { kemampuan menjawab } \\
\text { peserta tidak sama, sehingga } \\
\text { alangkah baiknya jika } \\
\text { pertanyaan yang muncul di } \\
\text { pre test dan post test tersebut } \\
\text { dibahas lebih mendalam, } \\
\text { sehingga bisa menambah } \\
\text { pemahaman peserta. Selain } \\
\text { itu soal dalam bentuk } \\
\text { jawaban essay dipandang } \\
\text { menyusahkan oleh peserta, } \\
\text { sebaiknya dalam bentuk } \\
\text { pilihan ganda saja. }\end{array}$ & $\begin{array}{l}\text { Tentunya saran perbaikan dari peserta ini } \\
\text { perlu diperhatikan untuk pembelajaran } \\
\text { berikutnya, supaya pembelajaran daring } \\
\text { bisa lebih efektif dengan pembahasan } \\
\text { materi yang lebih banyak dan memberikan } \\
\text { pemahaman yang komprehensif terhadap } \\
\text { peserta. Salah satu cara yang dapat } \\
\text { dilakukan yaitu dengan melakukan tes } \\
\text { formatif saat peserta melakukan belajar } \\
\text { mandiri sehingga pada saat pembelajaran } \\
\text { daring sudah dapat diketahui oleh } \\
\text { widyaiwara, materi yang paling banyak } \\
\text { dijawab salah oleh peserta. Sehingga } \\
\text { widayaiswara bisa menetapkan metode } \\
\text { pembelajaran yang paling efektif dan } \\
\text { efisien untuk memberikan pemahaman } \\
\text { kepada peserta. }\end{array}$ \\
\hline
\end{tabular}

\section{Kesimpulan}

Pembelajaran Kelas Daring CPNS Golongan III Kerjasama Pusdiklat Pegawai Kemendikbud dengan PPSDM Aparatur Angkatan 19 TA 2020 dalam pembelajaran Whole of Government dalam masa pandemi COVID-19 di Pusat Pengembangan Sumber Daya Manusia Aparatur KESDM diikuti oleh peserta dari 4 kota atau kabupaten dari tiga provinsi. Kelas daring sangat bergantung dengan internet, sebagian besar peserta jaringan internetnya lancar. Peserta sebelum tatap muka secara daring sudah belajar mandiri melalui SMILE, saat tatap muka dilakukan pendalaman materi dengan diskusi daring kemudian dilakukan post test. Hasil nilai post test rata-rata kelas adalah 95,6 atau sangat memuaskan, sedangkan nilai per peserta tertinggi dengan nilai 100 dan terendah 81 atau memuaskan, batas nilai minimal adalah $\leq 60$. Tindakan atau eksperimen pembelajaran mampu menyampaikan materi sampai 81\%-93\%. Kekurangan Pembelajaran Kelas Daring CPNS Golongan III Kerjasama Pusdiklat Pegawai Kemendikbud dengan PPSDM Aparatur Angkatan 19 TA 2020 diantaranya pemahaman peserta yang kurang, masalah waktu dan soal nya berharap pilihan ganda. Sedangkan kelebihannya mampu meningkatkan pemahaman peserta terhadap materi pembelajaran WOG serta tidak membosankan. Secara umum pembelajaran daring dinilai positif dan efektif oleh peserta sehingga dapat dilanjutkan baik pada masa pandemi maupun setelah masa pandemi ini berakhir. Peserta memberi saran perbaikan agar menambah pembahasan materi pembelajaran, bentuk soal esai diganti dengan soal pilihan ganda, dan menambah jumlah serta variasi soal. 


\section{Saran}

a. Perlu dilakukan pre test dan post test terlebih dahulu pada saat peserta belajar mandiri supaya bisa dipetakan, di materi mana peserta masih belum memahami pembelajaran, sehingga pembelajaran bisa difokuskan pada materi dan kompetensi yang belum difahami peserta

b. Sebaiknya soal prestest dan posttest dibuat dengan pilihan ganda, supaya tidak terlalu memakan waktu dalam pengerjaannya.

c. Soal post test dibuat sesuai dengan isi modul yang sudah disiapkan dan dibuat secara berurutan berdasarkan bab-bab dalam modul pada mata pelatihan Whole Of Government.

d. Perlu pengembangan metode pembelajaran lainnya sehingga bisa lebih memudahkan peserta dalam memahami pembelajaran yang dilakukan.

e. Untuk penyelenggara perlu tetap mengembangkan LMS yang digunakan dalam pembelajaran sehingga dapat lebih optimal dalam menjalankan pembelajaran secara daring (e-learning).

f. Pembelajaran e-learning ini baru di mulai di PPSDM Aparatur, sehingga baik widyaiswara maupun penyelenggara tetap harus mengembangkan pembelajaran secara daring ini supaya ke depan bisa lebih baik lagi.

\section{Daftar Pustaka}

retrieved from https://jdih.setneg.go.id/Produk, Keppres No. 9 Tahun 2020

retrieved from https://covid19.go.id/

Peraturan Kepala Lembaga Administrasi Negara (LAN) RI Nomor 12 Tahun 2018 tentang Pedoman Penyelenggaraan Pelatihan Dasar Calon Pegawai Negeri Sipil Golongan III

Surat Edaran Kepala LAN Nomor 10/K.1/HKM.02.3/2020 tentang Panduan Teknis Penyelenggaraan Pelatihan Dalam Masa Pandemi Corona Virus Disease (COVID-19)

UU No. 5 Tahun 2014 tentang Aparatur Sipil Negara.

Pane, A., \& Dasopang, M. D. (2017). Belajar Dan Pembelajaran. Aprida Pane Muhammad Darwis Dasopang. Jurnal Kajian Ilmu-Ilmu Keislaman, 3(2), 333-352.

Undang-undang Republik Indonesia Nomor 20 tahun 2003 tentang Sistem Pendidikan Nasional.

Fakhrurrazi. (2018). Hakikat Pembelajaran Yang Efektif. Jurnal At-Tafkir, 11, 86.

Bilfaqih, Y dan Qomarudin, N. (2015). Esensi Pengembangan Pembelajaran Daring. Yogyakarta: DEEPUBLISH.

Kuntarto, E. (2017). Keefektifan Model Pembelajaran Daring Dalam Perkuliahan Bahasa Indonesia Di Perguruan Tinggi. Indonesian Language Education and Literature, 03, 102.

Alimuddin., Tawany Rahamma., M. Nadjib. 2015. Intensitas Penggunaan E-Learning Dalam Menunjang Pemeblajaran Mahasiswa Program Sarjana (S1) Di Universitas Hasanuddin. Jurnal Komunikasi KAREBA, 4(4).

Kartika, A. R. (2018). Model Pembelajaran Daring. Journal of Early Childhood Care \& Education, 27.

Permendikbud no. 109 Tahun 2013 tentang Penyelenggaraan PJJ pada Pendidikan Tinggi.

Mustofa, Chodzirin, \& Sayekti, L. (2019). Formulasi Model Perkuliahan Daring Sebagai Upaya Menekan Disparitas Kualitas Perguruan Tinggi. Journal of Information Technology, 01, 154. 
Herayanti, \& Fuadunnazmi, \& H. (2017). Pengembangan Media Pembelajaran Berbasis Moodle Pada Matakuliah Fisika Dasar. Jurnal Cakrawala Pendidikan, 211.

Herayanti, \& Fuadunnazmi, \& H. (2017). Pengembangan Media Pembelajaran Berbasis Moodle Pada Matakuliah Fisika Dasar. Jurnal Cakrawala Pendidikan, 4.

Hadisi, dan Muna. (2015). Pengelolaan Teknologi Informasi Dalam Menciptakan Model Inovasi Pembelajaran ( E-Learning ). Jurnal Al-Ta'dib, 8, 127.

Hadisi, dan Muna. (2015). Pengelolaan Teknologi Informasi Dalam Menciptakan Model Inovasi Pembelajaran (E-Learning). Jurnal Al-Ta'dib, 8, 130.

Seno, \& Zainal, A. E. (2019). Persepsi Mahasiswa Terhadap Pelaksanaan ELearning Dalam Mata Kuliah Manajemen Sistem Informasi. Jurnal Kajian Teknologi Pendidikan, $02,183$.

Hendri. (2014). Pemanfaatan Sharable Content Object Reference Model Dalam Menciptakan Aplikasi Web E-Learning. Jurnal Media Sistem Informasi, 8, 24.

Hadisi, dan Muna. (2015). Pengelolaan Teknologi Informasi Dalam Menciptakan Model Inovasi Pembelajaran ( E-Learning ). Jurnal Al-Ta'dib, 8, 130.

Sari, P. (2015). Memotivasi Belajar Dengan Menggunakan E-Learning. Jurnal Ummul Qura, 6, 28-29.

McCusker, K., \& Gunaydin, S. (2015). Research using qualitative, quantitative or mixed methods and choice based on the research. Mukhtar. 2013. Metode Penelitian Deskriftif Kualitatif. Jakarta : GP Press Group.

Sugiyono. 2013. Metode Penelitian Kuantitatif, Kualitatif dan R\&D. Penerbit Alfabeta: Bandung.

Subana, M., Sudrajat, 2011, Dasar - Dasar Penelitian Ilmiah, Bandung: Pustaka Setia.

J. Creswell. Riset Pendidikan, Perencanaan, Pelaksanaan, dan Evaluasi Riset Kualitatif \& Kuantitatif, Kelima. Jakarta: Pustaka Pelajar, 2015.

L. J. Moleong. Metodologi Penelitian Kualitatif. Bandung: Remaja Rosdakarya, 2015.

A. Mertler. Action Research Mengembangkan Sekolah Memberdayakan Guru. Yogyakarta: Pustaka Pelajar, 2011. 